(c) American Dairy Science Association, 2002.

\title{
Effects of Pretrial Milk Yield on Responses of Feed Intake, Digestion, and Production to Dietary Forage Concentration
}

\author{
J. A. Voelker, G. M. Burato, and M. S. Allen \\ Department of Animal Science, \\ Michigan State University, \\ East Lansing 48824-1225
}

\section{ABSTRACT}

The relationships between pretrial milk yield and effects of dietary forage-to-concentrate ratio on dry matter intake (DMI), digestion, and milk yield were evaluated using 32 Holstein cows in a crossover design with two 16-d periods. Cows were $197 \pm 55$ (mean \pm SD) days in milk at the beginning of the experiment. Milk yield averaged $33.9 \mathrm{~kg} / \mathrm{d}$ and ranged from 16.5 to $55.0 \mathrm{~kg} / \mathrm{d}$ for the $4 \mathrm{~d}$ before initiation of treatments. Treatments were diets with forage-to-concentrate ratios of 67:33 and 44:56. Forages were alfalfa silage and corn silage, each at $50 \%$ of forage dry matter (DM). Neutral detergent fiber (NDF) concentrations of highforage and low-forage diets were 30.7 and $24.3 \%$ of DM, respectively. Dry matter intake was $1.7 \mathrm{~kg} / \mathrm{d}$ higher for cows fed the low-forage diet. Milk yield was $2.3 \mathrm{~kg} / \mathrm{d}$ greater on low forage than on high forage, but $3.5 \%$ fat-corrected milk yield and yield of milk fat were not different between treatments. Individual DMI response to the low-forage diet relative to the high-forage diet (low-high) was positively and linearly related to pretrial fat-corrected milk yield, but fat-corrected milk yield response demonstrated a quadratic relationship with pretrial fat-corrected milk yield. Milk yield responded more positively to low forage among low- and high-producing cows than among moderate-producing cows. Energy partitioned to body reserves and to milk, and passage rate of indigestible NDF, also responded to dietary forage level in quadratic relationships with pretrial milk energy output. Individual responses of intake, production, and fiber digestion to a change in forage-to-concentrate ratio were dependent on production level.

(Key words: milk yield, forage level, energy partitioning, ruminal digestion)

Abbreviation key: F:C = forage-to-concentrate ratio, $\mathbf{H F}=$ high-forage diet, INDP = indigestible neutral

Received November 9, 2001.

Accepted April 15, 2002.

Corresponding author: M. S. Allen; e-mail: allenm@msu.edu. detergent fiber, $\mathbf{L F}=$ low-forage diet, $\mathbf{p F C M Y}=$ pretrial $3.5 \%$ FCM yield, $\mathbf{p M E O}=$ pretrial milk energy output.

\section{INTRODUCTION}

Diet forage-to-concentrate ratio $(\mathbf{F}: \mathbf{C})$ affects feeding and digestion in dairy cows through both physical and chemical mechanisms. Physical controls include gut distension (Lehman, 1941) and limitations to time spent eating and ruminating (Allen, 2000). Altered fermentation acid production in the rumen resulting from changes in F:C may also affect intake and digestion responses to diet (Sheperd and Combs, 1998). Excess production of fermentation acids with low-forage diets results in lower ruminal $\mathrm{pH}$, which can decrease fiber digestibility (Hoover, 1986). Excess propionate production can result in lower feed intake, possibly from metabolism in the liver (Anil et al., 1993; Allen, 2000).

However, response to higher-energy diets and the extent to which fill limits intake depend on individual energy balance (Mertens, 1994; Allen, 1996). Therefore testing only treatment means may not detect important responses in intake, digestibility, and production (Allen, 2000). Oba and Allen (1999) found that on a diet containing corn silage with greater fiber digestibility, individual milk yield and feed intake responses increased linearly with pretrial milk yield. Digestion responses should be similarly related to production potential. We hypothesize that individual response to diets with different $\mathrm{F}$ :C depends on milk production level. The objective of this experiment was to evaluate the effects of pretrial milk yield on difference in response of feeding behavior, intake, digestion, and milk production to diets with high and low forage contents.

\section{MATERIALS AND METHODS}

\section{Cows and Treatments}

Twenty intact and 12 ruminally fistulated, multiparous Holstein cows (Table 1) in mid- to late lactation 
Table 1. Status of 29 cows at the beginning of the experiment. ${ }^{1}$

\begin{tabular}{lcc}
\hline Item & Mean & SD \\
\hline Parity & 2.6 & 1.0 \\
BW, kg & 670 & 61 \\
BCS & 2.79 & 0.65 \\
DIM & 197 & 55 \\
Milk yield, kg & 33.4 & 8.6 \\
\hline
\end{tabular}

${ }^{1}$ Data were collected from 32 cows for this experiment, but data from three cows were excluded due to illness and interference from nontrial cows.

$(197 \pm 55 ; \mathrm{X} \pm \mathrm{SD})$ at the Michigan State University Dairy Cattle Teaching and Research Center were fed each of two diets in a crossover design with two 16-d periods. Treatments were a high-forage $\operatorname{diet}(\mathbf{H F})$ and a low-forage diet (LF), with F:C of 67:33 and 44:56, respectively. Diets contained alfalfa silage ( $50 \%$ of forage DM), corn silage ( $50 \%$ of forage DM), high moisture corn, corn distillers grains, soybean meal, fat supplement, whole linted cottonseed, and a mineral and vitamin premix (Table 2). The diets were formulated to contain $17.5 \% \mathrm{CP}$, and the NDF concentration of the $\mathrm{HF}$ and $\mathrm{LF}$ diets were 30.7 and $24.3 \%$ of DM,

Table 2. Ingredient and nutrient composition of experimental diets.

\begin{tabular}{lcc}
\hline Composition & Low forage & High forage \\
\cline { 2 - 3 } & \multicolumn{2}{c}{$\%$ of DM } \\
\cline { 2 - 3 } Ingredient $^{2}$ & 21.8 & 32.9 \\
Corn silage $^{1}$ & 22.5 & 33.9 \\
Alfalfa silage $^{2}$ & 25.8 & 6.1 \\
High-moisture corn $^{\text {Soybean meal, 44\% CP }}$ & 9.4 & 6.6 \\
Whole linted cottonseed & 5.6 & 5.6 \\
Corn distillers grains & 3.4 & 3.5 \\
Fat supplement & 4.4 & 4.4 \\
Vitamin and mineral mix & 4.1 & 7.1 \\
Nutrient & 7.1 & 30.7 \\
NDF & 24.3 & 17.9 \\
CP & 18.0 & 23.1 \\
Starch & 33.8 & $67: 33$ \\
F:C & $44: 56$ & \\
\hline
\end{tabular}

${ }^{1}$ Corn silage was $30.4 \% \mathrm{DM}$ and contained $35.9 \% \mathrm{NDF}, 34.9 \%$ starch, and $9.1 \% \mathrm{CP}$ on a DM basis.

${ }^{2}$ Alfalfa silage was $50.9 \% \mathrm{DM}$ and contained $36.7 \% \mathrm{NDF}, 5.2 \%$ starch, and $18.3 \% \mathrm{CP}$ on a DM basis.

${ }^{3}$ Ultimate EXT 36\% (Purina Mills, Inc., St. Louis, MO): $39.6 \%$ CP, $7.50 \%$ NPN, $13.2 \%$ crude fat, $8.8 \% \mathrm{ADF}, 12.1 \% \mathrm{NDF}, 3.19 \%$ calcium, $1.10 \%$ phosphorus, $0.05 \%$ iron, $0.04 \%$ zinc, $0.01 \%$ copper, $0.04 \%$ manganese, $0.0002 \%$ iodine, $0.001 \%$ cobalt, $0.0003 \%$ selenium, and (per gram) 6.4 IU of vitamin A, 1.4 IU of vitamin D, 0.0227 IU of vitamin E.

${ }^{4}$ Vitamin and mineral mix contained $75.8 \%$ dry ground corn, $4.3 \%$ urea, $0.7 \%$ trace mineral mix, $0.55 \%$ mineral mix $(12.6 \%$ calcium, $9.1 \%$ phosphorus, $0.01 \%$ cobalt, $1 \%$ copper, $0.06 \%$ iodine, $5 \%$ iron, $4 \%$ manganese, $0.03 \%$ selenium, $4 \%$ zinc), $0.1 \%$ vitamin $\mathrm{D}$ ( $8.8 \mathrm{IU} /$ $\mathrm{g}), 0.1 \%$ vitamin A (30 IU/g), $0.4 \%$ selenium supplement $(0.198 \mathrm{~g} /$ $\mathrm{kg} \mathrm{Se}$ ), $8.6 \%$ sodium bicarbonate, $3.8 \%$ magnesium oxide, and $5.8 \%$ dicalcium phosphate.

${ }^{5}$ Forage-to-concentrate ratio.

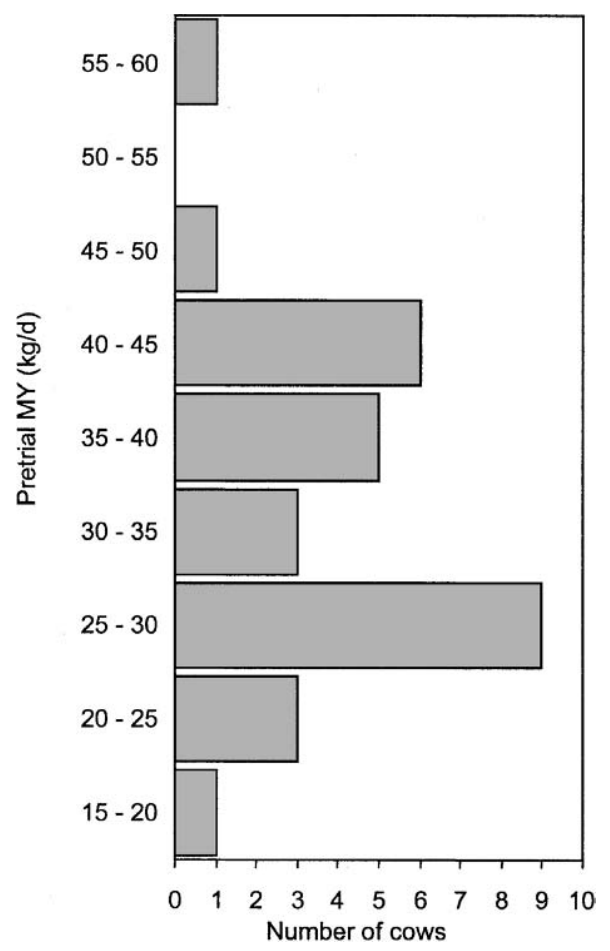

Figure 1. Distribution of pretrial milk yields of 29 cows used in statistical analysis. Data were collected from 32 cows for this experiment, but data from three cows were excluded due to illness and interference from nontrial cows.

respectively (Table 2). Cows were randomly assigned within the intact and fistulated groups to a treatment sequence. During the $4 \mathrm{~d}$ immediately prior to the experiment the cows were fed a common diet, and milk yield averaged $33.4 \mathrm{~kg} / \mathrm{d}$ and ranged from 16.5 to 55.0 $\mathrm{kg} / \mathrm{d}$ (Figure 1). Cows were housed in tie stalls throughout the experiment, except during milking and a 1.5-h outdoor exercise period before each milking. The cows were milked twice daily in the milking parlor at 0400 and $1400 \mathrm{~h}$. Samples and data were collected during the last $6 \mathrm{~d}$ of each period.

\section{Sample Collection}

Cows were fed once daily $(0900 \mathrm{~h})$ at $110 \%$ of expected intake. Amounts of feed offered and refused were weighed daily for each cow during d 11 to 16 . Samples of orts (1/8 of total) were collected daily and combined into one sample per period, per cow. Individual feed ingredients were sampled daily from d 11 to 16 and combined by period. Milk yield was recorded, and milk samples were collected, at each milking from d 11 to 14 .

Feeding behavior was recorded manually every 5 min for $24 \mathrm{~h}$ on $\mathrm{d} 11$. Activity was classified as eating, 
ruminating, drinking, or idle. Feeding and milking times and procedures were not altered during feeding behavior observation.

Fecal grab samples were collected from each cow at 18-h intervals on d 12 to 14, yielding four samples per cow per period. Rumen contents were evacuated manually through the rumen fistula at $1200 \mathrm{~h}(3 \mathrm{~h}$ postfeeding) on $\mathrm{d} 15$ and at $0600 \mathrm{~h}$ ( $3 \mathrm{~h}$ prefeeding) on $\mathrm{d} 16$. Total rumen content mass and volume were recorded. To more accurately sample rumen contents, a $10 \%$ subsample obtained during evacuation was strained through a layer of nylon mesh (approximately 1-mm pore size) to separate solid and liquid phases. Samples of each phase were taken to determine rumen pool size of nutrients, and an additional liquid sample was taken to determine pool size of volatile fatty acids.

Body weight was recorded on the day before the first period and on d 16 of each period to determine BW change. On the same days, BCS was determined by three trained investigators using a five-point scale [1 = thin, 5 = fat; (Wildman et al., 1982).

\section{Sample Analyses}

Milk samples were analyzed for fat, true protein, and lactose with infrared spectroscopy by Michigan DHIA (East Lansing). Diet ingredients and orts were dried in a $55^{\circ} \mathrm{C}$ forced-air oven for $48 \mathrm{~h}$, and fecal samples were dried for $72 \mathrm{~h}$. All samples were ground with a Wiley mill (1-mm screen; Arthur H. Thomas, Philadelphia, PA). Diet ingredients were analyzed for $\mathrm{DM}, \mathrm{NDF}, \mathrm{ADF}$, lignin, starch, sugar, CP, ether extract, ash, and indigestible NDF concentrations. Fecal samples were analyzed for DM, NDF, starch, sugar, $\mathrm{CP}$, indigestible NDF, and ash contents. Concentrations of NDF, ADF, and acid detergent-sulfuric acid lignin were determined nonsequentially (Goering and Van Soest, 1970) with the addition of heat-stable amylase as per Van Soest et al. (1991, method A). Starch was measured by an enzymatic method (Karkalas, 1985) after samples were gelatinized with sodium hydroxide. Crude protein was analyzed according to Hach et al. (1987). Ether extract was measured using the AOAC method (1990) modified for a multiple-sample Soxhlet apparatus. Ash content was determined after $5 \mathrm{~h}$ of oxidation at $500^{\circ} \mathrm{C}$ in a muffle furnace. Indigestible NDF (INDF) was estimated as NDF residue after $120 \mathrm{~h}$ of in vitro fermentation (Goering and Van Soest, 1970). All nutrient concentrations except DM were expressed as percentages of DM determined from drying at $105^{\circ} \mathrm{C}$ in a forced-air oven. Apparent total tract digestibility of DM, OM, NDF, starch, and $\mathrm{CP}$ were calculated using indigestible NDF as an in- ternal marker (Cochran et al., 1986). Rumen contents were dried by lyophilization (Tri-Philizer MP, FTSSYSTEMS Stone Ridge, New York) and analyzed for DM, NDF, starch, and indigestible NDF as previously described. Dry matter of rumen contents was determined by both toluene (AOAC, 1990) and lyophilization methods. Concentration of major rumen VFA and their molar percentages were analyzed by HPLC, according to Weimer et al. (1999).

\section{Statistical Analyses}

For treatment effects, all data were analyzed by the fit model procedure of JMP (JMP, 2000) according to the following model:

$$
\mathrm{Y}_{\mathrm{ijkl}}=\mu+\mathrm{S}_{\mathrm{i}}+\mathrm{C}_{\mathrm{j}}\left(\mathrm{S}_{\mathrm{i}}\right)+\mathrm{P}_{\mathrm{k}}+\mathrm{T}_{\mathrm{l}}+\mathrm{e}_{\mathrm{ijkl}}
$$

where

$$
\begin{aligned}
\mu & =\text { overall mean, } \\
\mathrm{S}_{\mathrm{i}}= & \text { effect of sequence }(\mathrm{i}=1 \text { to } 2), \\
\mathrm{C}_{\mathrm{j}}\left(\mathrm{S}_{\mathrm{i}}\right)= & \text { effect of cow nested in sequence }(\mathrm{j}=1 \text { to } \\
& 16), \\
\mathrm{P}_{\mathrm{k}}= & \text { effect of period }(\mathrm{k}=1 \text { to } 2), \\
\mathrm{T}_{\mathrm{l}}= & \text { effect of treatment }(\mathrm{l}=1 \text { to } 2), \\
\mathrm{e}_{\mathrm{ijkl}}= & \text { residual, assumed to be normally distrib- } \\
& \text { uted. }
\end{aligned}
$$

To correlate response to treatment with pretrial milk production, the response $(\Delta \mathrm{Y})$ was calculated as follows:

$$
\Delta \mathrm{Y}=\mathrm{y}_{\text {low }}-\mathrm{y}_{\text {high }}
$$

where

$$
\begin{aligned}
\mathrm{y}_{\text {low }} & =\text { response for the low-forage diet, and } \\
\mathrm{y}_{\text {high }} & =\text { response for the high-forage diet. }
\end{aligned}
$$

Pretrial FCM yield (pFCMY) and pre-trial milk net energy output (pMEO) were calculated as the average of eight milkings over the $4 \mathrm{~d}$ immediately before the initiation of the experiment. Pretrial MEO was calculated as follows: $\mathrm{NE}_{\mathrm{L}(\text { milk })}(\mathrm{Mcal} / \mathrm{d})=\mathrm{MY}(\mathrm{kg}) \times[0.0929$ $\times($ Fat \% $)+0.0563 \times($ True Protein \% $)+0.0395 \times($ Lactose\%)] (NRC, 2001). Relationships between response to treatment and pFCMY or pMEO were analyzed according to the following model:

$$
\mathrm{Y}_{\mathrm{i}}=\mu+\mathrm{S}_{\mathrm{i}}+\mathrm{pM}+\mathrm{pM}^{2}+\mathrm{e}_{\mathrm{i}}
$$

where

$$
\mathrm{Y}_{\mathrm{i}}=\mathrm{y}_{\text {low }}-\mathrm{y}_{\text {high }}
$$


Table 3. Least squares means, standard errors, and significance of effects of dietary fiber concentration on feed intake and production.

\begin{tabular}{|c|c|c|c|c|}
\hline & Low forage & High forage & SE & $P$ \\
\hline \multicolumn{5}{|l|}{ Intake } \\
\hline $\mathrm{DM}$ & 23.7 & 22.0 & 0.3 & $<0.0001$ \\
\hline NDF & 5.6 & 6.5 & 0.1 & $<0.0001$ \\
\hline Indigestible NDF & 2.9 & 3.3 & 0.04 & $<0.0001$ \\
\hline Starch & 8.1 & 5.2 & 0.1 & $<0.0001$ \\
\hline $\mathrm{CP}$ & 4.2 & 3.9 & 0.1 & $<0.0001$ \\
\hline \multicolumn{5}{|l|}{ Yield } \\
\hline Milk & 33.3 & 31.0 & 0.6 & $<0.01$ \\
\hline $3.5 \% \mathrm{FCM}^{1}$ & 35.2 & 34.1 & 0.7 & 0.16 \\
\hline $\mathrm{SCM}^{2}$ & 32.2 & 31.2 & 0.5 & 0.09 \\
\hline Fat & 1.28 & 1.29 & 0.03 & 0.81 \\
\hline Protein & 1.01 & 0.94 & 0.02 & $<0.001$ \\
\hline Lactose & 1.50 & 1.55 & 0.08 & 0.15 \\
\hline \multicolumn{5}{|l|}{ Milk Composition } \\
\hline Fat & 3.89 & 4.16 & 0.08 & $<0.01$ \\
\hline Protein & 2.87 & 2.76 & 0.05 & 0.08 \\
\hline Lactose & 4.62 & 4.70 & 0.07 & 0.20 \\
\hline BW change, kg/d & 1.82 & 1.16 & 0.03 & 0.06 \\
\hline BCS change ${ }^{3}$ & 0.13 & 0.03 & 0.05 & 0.06 \\
\hline
\end{tabular}

${ }^{1} 3.5 \%$ FCM yield $(\mathrm{kg} / \mathrm{d})$.

${ }^{2}$ Solids-corrected milk yield $(\mathrm{kg} / \mathrm{d})$.

${ }^{3}$ Change in BCS (five-point scale where $1=$ thin to $5=$ fat) over a 16-d period.

$$
\begin{aligned}
\mu= & \text { overall mean } \\
\mathrm{S}_{\mathrm{i}} & =\text { effect of sequence }(\mathrm{i}=1 \text { to } 2) \\
\mathrm{pM} & =\mathrm{pFCMY} \text { or } \mathrm{pMEO}, \\
\mathrm{pM}^{2} & =\mathrm{pFCMY}^{2} \text { or } \mathrm{pMEO}^{2}, \text { and } \\
\mathrm{e}_{\mathrm{i}}= & \text { residual, assumed to be normally distrib- } \\
& \text { uted. }
\end{aligned}
$$

Data from three cows were excluded from statistical analysis; one cow developed mastitis, one cow had diarrhea accompanied by a fever, and a cannulated cow had feed stolen by nontrial cows during the collection period. Data in Table 1 are for the 29 cows used in the statistical analysis.

\section{RESULTS AND DISCUSSION}

\section{Intake and Production}

Dry matter intake was higher by $1.7 \mathrm{~kg} / \mathrm{d}(P<$ 0.0001) when cows were fed the LF diet (Table 3). Starch intake was greater $(P<0.0001)$ on $\mathrm{LF}$, and $\mathrm{NDF}$ intake was greater $(P<0.0001)$ on the HF diet. Intake of CP reflected higher DMI on LF. No interaction was found between effects of treatment and cannulation, so treatment means are reported for all cows without a separate analysis within the cannulated group.

Milk yield was $2.3 \mathrm{~kg} / \mathrm{d}$ greater $(P<0.01)$ for $\mathrm{LF}$ than for HF (Table 3). However, 3.5\% FCM yield was not significantly affected by treatment. Yield of milk fat was unaffected by dietary forage level, but yield was greater for true protein $(P<0.001)$ for $L F$ than for HF. Milk fat content was 0.27 percentage units lower $(P<0.01)$, and true protein content tended to be higher $(P=0.08)$ for cows fed LF than for cows fed HF. Treatment effects for milk yield and fat content were similar to a previous study in which feeding a low forage diet resulted in greater milk yield but a lower milk fat concentration (Grummer et al., 1987).

Cows may have gained more body tissue when fed LF, because a tendency was detected for greater increases of both BW $(P=0.06)$ and BCS $(P=0.06)$ on LF than on HF (Table 3). Any increase in BW might have resulted from tissue accretion and/or increased gut fill. However, it is unlikely that gut contents were greater for $\mathrm{LF}$ than for $\mathrm{HF}$ because rumen digesta weight in cannulated cows was $6.5 \mathrm{~kg}$ higher $(P<0.01)$ on HF (Table 9).

Failure to detect a statistical difference in FCM yield may be, in part, the result of high variation in milk yield within the group and subsequent variation in response to treatment. The difference in individual response in FCM yield to diet LF relative to response to diet HF (LF-HF), when weighted by treatment sequence, was regressed against the individual pretrial FCM yield (pFCMY) (quadratic $P=0.02$; Table 4). This yield was measured while cows were fed a common diet during the $4 \mathrm{~d}$ immediately before the start of the experiment. To aid in visualizing this relationship across production levels, the relationship obtained by regression (and all such relationships to follow) was plotted while holding sequence equal to zero (Figure 2a). This quadratic relationship indicates that the milk yields of the lowest- and highest-producing cows responded more positively to a low NDF diet than did the yields of cows with moderate production and that the greatest response occurred among high producing cows. A previous experiment (Oba and Allen, 1999), using cows with a narrower range of production and higher minimum milk yield, reported a positive linear correlation of response to increased forage fiber digestibility with increasing pretrial milk yield.

Response of FCM was also regressed on $\mathrm{pFCMY}$ corrected for pretrial metabolic BW (pFCMY/BW ${ }^{0.75}$ ) to determine the extent to which the wide range in BW of cows in this experiment (Table 1) was responsible for the quadratic relationship. A similar relationship was observed between FCM response and pFCMY, and between FCM response and pFCMY/ $\mathrm{BW}^{0.75}$ (data not shown), leading to the conclusion that the quadratic relationship was independent of BW differences. In addition, DIM at the start of the experiment was tested as a covariant with pFCMY and did not contribute significantly to the regression. 
Table 4. Responses (low forage-high forage) of intake and production by pretrial 3.5\% FCM yield (pFCMY).

\begin{tabular}{|c|c|c|c|c|c|}
\hline Response & $\mathrm{R}^{2}$ & Predictor & $P$ & Coefficient & Intercept \\
\hline $\mathrm{MY}(\mathrm{kg} / \mathrm{d})$ & 0.729 & $\begin{array}{l}\text { Sequence } \\
\text { pFCMY } \\
\text { pFCMY }^{2}\end{array}$ & $\begin{array}{l}<0.001 \\
<0.01 \\
<0.001\end{array}$ & $\begin{array}{c}-2.17 \\
-1.24 \\
0.019\end{array}$ & 21.29 \\
\hline $3.5 \% \mathrm{FCM}(\mathrm{kg} / \mathrm{d})$ & 0.591 & $\begin{array}{l}\text { Sequence } \\
\text { pFCMY } \\
\text { pFCMY }^{2}\end{array}$ & $\begin{array}{c}<0.01 \\
0.04 \\
0.02\end{array}$ & $\begin{array}{c}-2.40 \\
-1.13 \\
0.017\end{array}$ & 18.24 \\
\hline DMI $(\mathrm{kg} / \mathrm{d})$ & 0.618 & $\begin{array}{l}\text { Sequence } \\
\text { pFCMY }\end{array}$ & $\begin{array}{l}<0.0001 \\
<0.01\end{array}$ & $\begin{array}{r}-1.74 \\
0.10\end{array}$ & -2.05 \\
\hline Digestible DMI (kg/d) & 0.647 & $\begin{array}{l}\text { Sequence } \\
\text { pFCMY }\end{array}$ & $\begin{array}{l}<0.0001 \\
<0.01\end{array}$ & $\begin{array}{r}-1.29 \\
0.07\end{array}$ & -1.51 \\
\hline
\end{tabular}

This quadratic response suggests that different factors controlled production response to diet among lowto moderate-producing cows and among moderate to high producers. Milk yield is generally correlated with DMI (NRC, 2001), and in these cows, DMI response to $\mathrm{LF}$ compared to HF (LF-HF) increased linearly
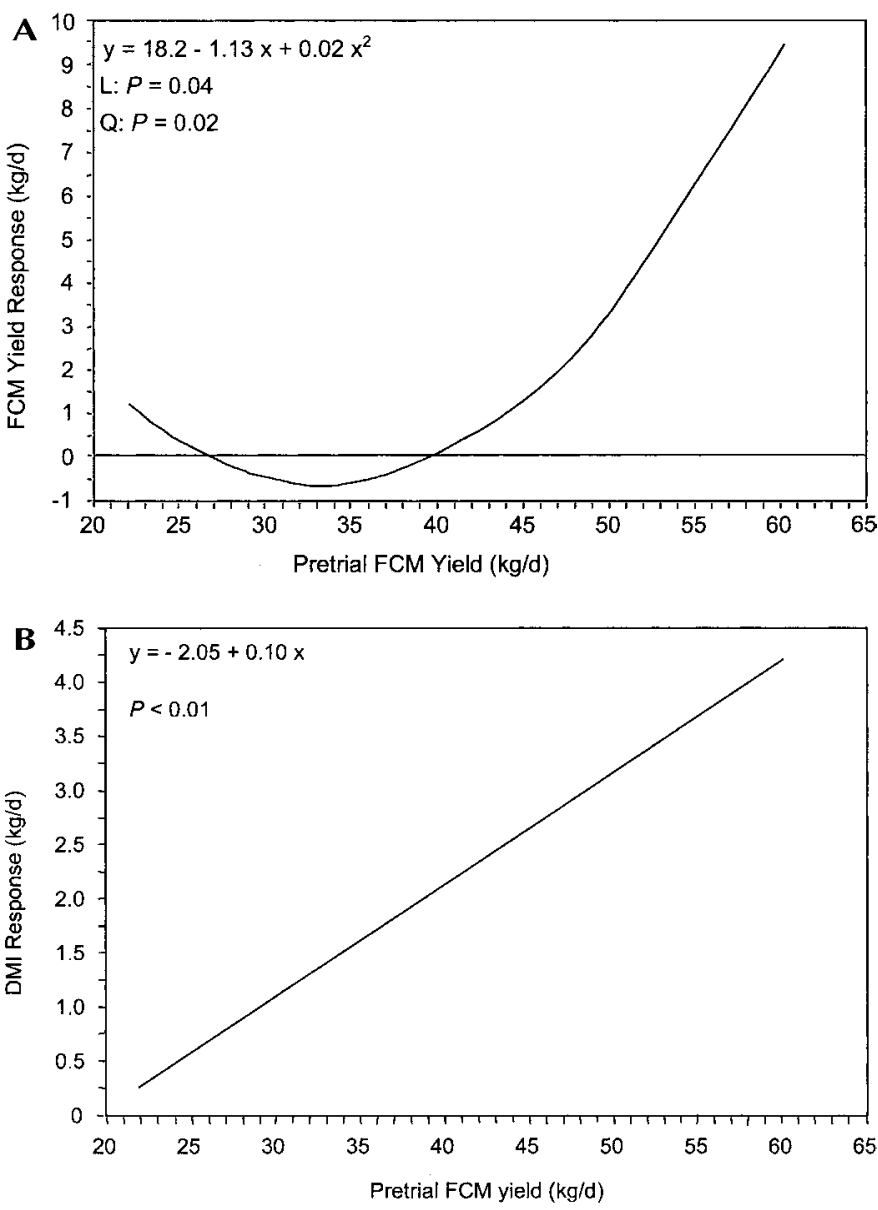

Figure 2. Relationship between mean 3.5\% FCM yield over $4 \mathrm{~d}$ before the beginning of the experiment and the response to the lowforage over the high-forage diet (LF-HF) in (A) 3.5\% FCM yield or (B) DMI. with pFCMY (Figure 2b) and pFCMY/BW ${ }^{0.75}$ (data not shown). Therefore, as pretrial production level increased, intake was increasingly limited on HF relative to LF. This increase in feed intake response to LF would then result in increased milk production (Figure 2a) or body reserves among moderate- to highproducing cows. Among low- to moderate-producing cows, the decrease in production response on LF relative to $\mathrm{HF}$ with increasing $\mathrm{pFCMY}$ does not correspond to the positive feed intake response. The production response may have also been affected by differences in energy partitioning, which will be discussed in a later section.

\section{Total Tract Digestibility}

Total tract DM digestibility was not different between the two diets (Table 5). Starch generally has greater whole tract digestibility than fiber (NRC, 2001) and was a greater proportion of LF (Table 2), so LF might be expected to have greater in vivo digestibility. However, both NDF digestibility and starch digestibility were greater $(P<0.0001)$ for cows fed $\mathrm{HF}$, so that DM digestibility was unaffected by dietary NDF level. Others investigating the effects of varying forage to concentrate ratios have reported either increased DM digestibility for diets with lower forage contents (Dado and Allen, 1995) or no significant effect (Wheeler et al., 1975; Alhadhrami and Huber, 1992). Diets with high forage fiber contents result in a larger rumen mat than do low forage diets, so feed particles

Table 5. Least squares means, standard errors, and significance of effects of dietary fiber concentration on total tract digestibility.

\begin{tabular}{lllll}
\hline Digestibility & Low forage & High forage & SE & $P$ \\
\cline { 2 - 4 } & \multicolumn{3}{c}{$\%$} & \\
DM & 60.6 & 59.9 & 0.6 & 0.33 \\
OM & 61.6 & 61.5 & 0.6 & 0.96 \\
NDF & 25.0 & 31.7 & 1.1 & $<0.0001$ \\
Starch & 86.1 & 90.2 & 0.7 & $<0.0001$ \\
CP & 63.6 & 62.6 & 0.6 & 0.18 \\
\hline
\end{tabular}


Table 6. Least squares means, standard errors, and significance of effects of dietary fiber concentration on energy intake and partitioning.

\begin{tabular}{lllll}
\hline $\mathrm{NE}_{\mathrm{L}}(\mathrm{Mcal} / \mathrm{d})$ & Low forage & High forage & $\mathrm{SE}$ & $P$ \\
\hline Intake $^{1}$ & 35.9 & 33.1 & 0.5 & $<0.0001$ \\
Milk $^{2}$ & 22.8 & 21.6 & 0.4 & $<0.01$ \\
Milk (\% intake) $_{\text {Reserve }}^{3}$ & 63.0 & 64.8 & 1.2 & 0.23 \\
Reserve (\% intake) & 2.53 & 1.01 & 0.57 & 0.03 \\
\hline
\end{tabular}

${ }^{1} \mathrm{NE}_{\mathrm{L}(\text { intake })}=\mathrm{DMI}(\mathrm{kg}) \times[0.0245 \times \mathrm{TDN}(\%)](\mathrm{NRC} 1989)$.

${ }^{2} \mathrm{NE}_{\mathrm{L}(\text { milk })}(\mathrm{Mcal} / \mathrm{d})=\mathrm{MY}(\mathrm{kg}) \times(0.0929 \times$ fat $\%+0.0563 \times$ true protein $\%+0.0395 \times$ lactose $\%)($ NRC 2001).

${ }^{3} \mathrm{NE}_{\mathrm{L}(\text { reserve })}=\mathrm{NE}_{\mathrm{L} \text { (intake) }}-\mathrm{NE}_{\mathrm{L} \text { (maintenance) }}-\mathrm{NE}_{\mathrm{L} \text { (milk) }}$, where $\mathrm{NE}_{\mathrm{L} \text { (main- }}$ tenance) $=0.080 \times \mathrm{BW}^{0.75}(\mathrm{NRC} 2001)$ using pretrial $\mathrm{BW}(\mathrm{kg})$.

of any size may be retained in the rumen longer and, therefore, be more completely digested (Grant, 1997). High-forage diets also generally result in higher ruminal $\mathrm{pH}$, which permits more extensive rumen microbial fermentation (Hoover, 1986). Responses of DM, $\mathrm{NDF}$, and starch digestibility were not correlated to pFCMY.

\section{Energy Partitioning}

Intake of $\mathrm{NE}_{\mathrm{L}}$, like DMI, was higher $(P<0.0001)$ when cows were fed LF (Table 6). Energy output in milk was $1.2 \mathrm{Mcal} / \mathrm{d}$ greater $(P<0.0001)$ on $\mathrm{LF}$ than on $\mathrm{HF}$, but energy in milk as a percentage of $\mathrm{NE}_{\mathrm{L}}$ intake was not significantly affected by treatment $(P$ $=0.23$ ). Cows on LF were in greater positive energy balance $(P=0.03)$ and retained more energy as a percentage of energy intake $(P=0.03)$, which is reflected in tendencies toward increases in BW and BCS on LF (Table 3).

Similar to relationships found between pFCMY and responses in DMI and milk yield, $\mathrm{NE}_{\mathrm{L}}$ intake response to $\mathrm{LF}$ over $\mathrm{HF}$ was linearly related $(P<0.01)$ to $\mathrm{pMEO}$ (Table 7), and milk $\mathrm{NE}_{\mathrm{L}}$ response ( $\mathrm{LF}-\mathrm{HF}$ ) had a quadratic correlation with pMEO $(P<0.001$; Figures $3 a, b)$. Differences in energy partitioning were also detected. Dilution of maintenance with increasing production tended to be greater for cows fed LF (Figure 3c). Net energy for maintenance as a percentage of intake was lower on LF across the range of production, and the difference increased with pMEO, so that the more milk cows produced, the greater was the proportion of energy available on LF over HF for production and reserves. Response of milk energy as a percent of absorbed energy tended to have a quadratic relationship to pMEO (Figure 3d), indicating that low-producing and high-producing cows put a greater proportion of $\mathrm{NE}_{\mathrm{L}}$ intake into milk on LF than on HF. Among moderate producers, the percentage of absorbed en- ergy devoted to milk was lower on LF than on HF (Figure 3d). Consistent with this, the responses of energy balance and energy reserve as a percentage of intake (Figure 3e,f) tended toward an opposite, quadratic relationship to pMEO. Therefore, in cows on the high and low ends of production, a higher percentage of energy absorbed tended to be used for milk, and less for tissue accretion, on the low-forage diet versus the high-forage diet. Low-producing cows likely had sufficient body reserves so that additional energy available on LF might have been used for milk production; then, as production potential increased from low to moderate, cows might have stored a greater proportion of intake energy (Figure 3f). Among high-producing cows, as energy intake response increased (Figure 3a), the response in percentage of intake used for maintenance decreased (Figure $3 c$ ), thus freeing a greater fraction of the extra absorbed energy on LF to be used for milk or replenishment of body reserves rather than for maintenance. The mechanism(s) of energy partitioning cannot be determined with the measurements obtained in this study, but it appears that high-producing cows preferentially increased milk production over body reserves on LF (Figure 3d,f).

\section{Chewing Behavior}

Cows spent similar amounts of time eating when fed HF or LF but spent more time ruminating $(P=$ $0.03)$ and in total chewing $(P=0.04)$ for HF than for LF (Table 8). Dado and Allen (1995) and Johnson and Combs (1992) also used diets based on alfalfa silage and corn silage, with NDF contents of 26 and $35 \%$, and 27 and 33\%, respectively. Both reported increased eating and total chewing times for cows fed the highfiber diets, and the first study found that the $35 \%$ NDF diet increased rumination time over the $26 \%$ NDF diet. Diet particle size, which was not measured in the present study, might result in different responses to different F:C across experiments. Eating and chewing time may have limited intake for cows fed HF, since they presumably would have increased intake, if possible, to increase their energy balance.

Eating, ruminating, and total chewing time per kilogram of DMI were lower $(P<0.01, P<0.0001$, and $P$ $<0.0001$, respectively) for cows fed $24 \%$ NDF than for cows fed $31 \%$ NDF (Table 8). However, cows fed LF also spent more time eating and ruminating per kilogram of NDF intake $(P<0.01, P<0.001)$ and forage NDF intake $(P<0.0001, P<0.0001)$ than did cows fed HF. Therefore, cows eating HF probably swallowed larger forage particles, and the rate and extent of particle size reduction was likely reduced, leading to 
Table 7. Responses (low forage-high forage) of energy intake and partitioning by pretrial milk $\mathrm{NE}_{\mathrm{L}}$ output (pMEO). ${ }^{1}$

\begin{tabular}{|c|c|c|c|c|c|}
\hline Response & $\mathrm{R}^{2}$ & Predictor & $P$ & Coefficient & Intercept \\
\hline $\mathrm{NE}_{\mathrm{L}}$ intake $(\mathrm{Mcal} / \mathrm{d})$ & 0.59 & $\begin{array}{l}\text { Sequence } \\
\text { pMEO }\end{array}$ & $\begin{array}{l}<0.0001 \\
<0.01\end{array}$ & $\begin{array}{r}-2.73 \\
0.26\end{array}$ & -3.72 \\
\hline Milk $\mathrm{NE}_{\mathrm{L}}(\mathrm{Mcal} / \mathrm{d})$ & 0.73 & $\begin{array}{l}\text { Sequence } \\
\text { pMEO } \\
\text { pMEO }^{2}\end{array}$ & $\begin{array}{l}<0.01 \\
<0.001 \\
<0.001\end{array}$ & $\begin{array}{c}-0.96 \\
-1.25 \\
0.028\end{array}$ & 13.99 \\
\hline $\mathrm{NE}_{\mathrm{L}}$ maintenance $\left(\% \mathrm{NE}_{\mathrm{L}}\right.$ intake $)$ & 0.59 & $\begin{array}{l}\text { Sequence } \\
\text { pMEO }\end{array}$ & $\begin{aligned}< & 0.0001 \\
& 0.06\end{aligned}$ & $\begin{array}{l}2.60 \\
-0.15\end{array}$ & 1.30 \\
\hline Milk $\mathrm{NE}_{\mathrm{L}}\left(\% \mathrm{NE}_{\mathrm{L}}\right.$ intake $)$ & 0.17 & $\begin{array}{l}\text { pMEO } \\
\text { pMEO }^{2}\end{array}$ & $\begin{array}{l}0.05 \\
0.06\end{array}$ & $\begin{array}{r}-3.32 \\
0.06\end{array}$ & 40.02 \\
\hline $\mathrm{NE}_{\mathrm{L}}$ balance $(\mathrm{Mcal} / \mathrm{d})$ & 0.25 & $\begin{array}{l}\text { Sequence } \\
\text { pMEO } \\
\text { pMEO }^{2}\end{array}$ & $\begin{array}{l}0.02 \\
0.11 \\
0.13\end{array}$ & $\begin{array}{c}-1.72 \\
1.30 \\
-0.023\end{array}$ & -15.11 \\
\hline $\mathrm{NE}_{\mathrm{L}}$ reserve $\left(\% \mathrm{NE}_{\mathrm{L}} \text { intake }\right)^{2}$ & 0.26 & $\begin{array}{l}\text { Sequence } \\
\text { pMEO } \\
\text { pMEO }^{2}\end{array}$ & $\begin{array}{l}0.02 \\
0.10 \\
0.13\end{array}$ & $\begin{array}{c}-1.47 \\
3.56 \\
-0.064\end{array}$ & -42.37 \\
\hline
\end{tabular}

\footnotetext{
${ }^{1}$ Pretrial milk NE output, calculated for $4 \mathrm{~d}$ before beginning of experiment: $\mathrm{NE}_{\mathrm{L}}(\mathrm{Mcal} / \mathrm{d})=\mathrm{MY}(\mathrm{kg} / \mathrm{d}) \times$
} $(0.0929 \times$ fat $\%+0.0563 \times$ true protein $\%+0.0395 \times$ lactose $\%)($ NRC 2001).

${ }^{2} 100 *\left(\mathrm{NE}_{\mathrm{L}}\right.$ balance/ $\mathrm{NE}_{\mathrm{L}}$ intake $)$.

greater rumen fill and more time to digest fiber on HF. Differences in chewing responses to the two diets were not correlated with pFCMY or pMEO.

\section{Ruminal Digestion}

Rumen turnover time of NDF was $2.6 \mathrm{~h}$ shorter $(P$ $<0.01$ ) in cows fed HF (Table 9). The shorter turnover time of NDF in HF cows could have resulted from an increased rate of passage or digestion. The passage rate of INDF from the rumen was not significantly affected by F:C (Table 9), so the shorter NDF turnover time on HF probably resulted from an increased rate of NDF digestion. Ruminal pH (not measured) might have affected the rate of NDF digestion, but due to the buffering capacity of rumen fluid, a change in digestibility may not always be accompanied by a change in $\mathrm{pH}$. The differences in response of rumen NDF turnover time and INDF passage rate to treatment were also dependent on production level, as discussed below.

Although NDF intake and chewing behavior were affected by dietary NDF level, rumen pools of NDF and digestible NDF were not different between treatments (Table 9). A larger NDF pool might be expected when feeding a high NDF diet, due to slower fermentation of NDF than of soluble carbohydrates. Other studies of F:C (Johnson and Combs, 1992; Dado and Allen, $1995)$ reported higher NDF pools for cows consuming the higher-fiber treatments. In the present study, the similar pool sizes of NDF on the two diets, combined with higher DMI on LF and higher NDF intake on $\mathrm{HF}$, are consistent with the concepts of fill-limited intake on the high-fiber diet and the faster escape of fiber from the rumen on HF due to physical fill. However, as will be demonstrated, this response varied with pretrial production level, so the average treatment effects of forage level on fiber disappearance are dependent on the mean and variation of milk yield in the group.

Although intake of DM was higher for LF, neither rumen turnover time of DM nor rumen pool of DM was affected by dietary forage level (Table 9 ). Rumen starch pool was greater $(P=0.01)$ in cows fed LF than in cows fed HF (0.96 kg vs. $0.62 \mathrm{~kg})$ as a result of greater starch intake (Table 3 ). Rumen digesta weight and volume were greater $(P<0.01, P=0.02)$ on $\mathrm{HF}$ than on $\mathrm{LF}$, but rumen digesta density was $0.84 \mathrm{~kg} /$ $\mathrm{L}$ for both diets.

Forage-to-concentrate ratio can also affect rumen VFA production. In this study, the total rumen VFA pool and concentration were similar between diets (Table 10). The acetate pool was $0.83 \mathrm{~mol}$ higher on HF than on $\operatorname{LF}(P<0.01)$, and the acetate to propionate ratio was higher $(P<0.0001)$ on HF $(2.96)$ than on LF (2.32). Acetate as a percentage of total VFA was higher, and percent propionate was lower $(P<0.0001)$, on HF than on LF.

Response in turnover time of NDF in the rumen $(\mathrm{LF}-\mathrm{HF})$ had a quadratic relationship with $\mathrm{pMEO}(P$ $=0.04$; Table 11), increasing with energy output in low-producing cows, then decreasing in cows with higher energy demands for lactation (Figure 4a). Tendencies for similar relationships were demonstrated between pMEO and responses of NDF pool ( $P$ $=0.09$; Figure $4 \mathrm{~b})$ and NDF digestibility $(P=0.09$; Figure 4c); the inverse was true for passage rate $\left(\mathrm{k}_{\mathrm{p}}\right)$ of indigestible NDF ( $P=0.02$; Figure $4 \mathrm{~d})$. These qua- 

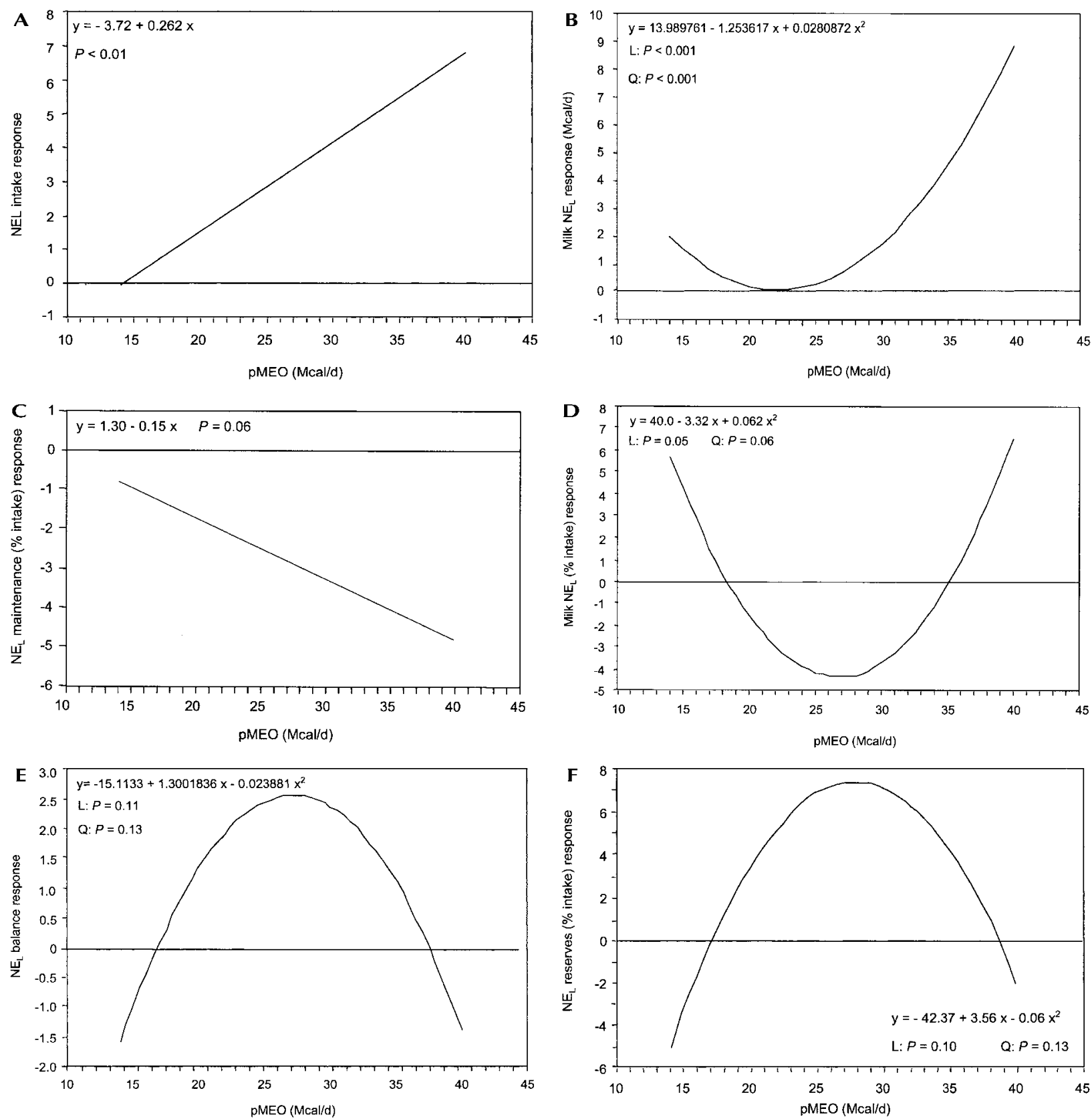

Figure 3. Relationship between mean pretrial milk $\mathrm{NE}_{\mathrm{L}}$ output over $4 \mathrm{~d}$ before the beginning of the experiment (pMEO) and the response to the low-forage over the high-forage diet $(\mathrm{LF}-\mathrm{HF})$ in $(\mathrm{A}) \mathrm{NE}_{\mathrm{L}}$ intake, (B) milk $\mathrm{NE}_{\mathrm{L}}$, (C) $\mathrm{NE}_{\mathrm{L}}$ for maintenance as a percentage of $\mathrm{NE} \mathrm{L}_{\mathrm{L}}$ intake, (D) milk $\mathrm{NE}_{\mathrm{L}}$ as a percentage of $\mathrm{NE}_{\mathrm{L}}$ intake, $(\mathrm{E}) \mathrm{NE}_{\mathrm{L}}$ balance, or $(\mathrm{F}) \mathrm{NE}_{\mathrm{L}}$ reserves as a percentage of $\mathrm{NE}_{\mathrm{L}}$ intake.

dratic relationships suggest that at least two different factors predominantly limited feed intake and passage of NDF in different ranges of production.

Among low- to moderate-producing cows, the relative responses to $\mathrm{LF}$ and $\mathrm{HF}$ appeared to result from a greater filling effect for HF. As pretrial production increased from low to moderate and intake increased to meet energy needs, NDF turnover time became in- creasingly longer on LF relative to HF (Figure 4a). As pMEO increased from low to moderate, the INDF passage rate increased more greatly on HF than on LF (Figure 4d), possibly because HF was more filling. As the milk yield of cows increased, the increasing response (LF-HF) in turnover time of NDF and the slower increase in passage rate of INDF increased the rumen NDF pool more on LF than on HF (Figure 
Table 8. Least squares means, standard errors, and significance of effects of dietary fiber concentration on chewing activities.

\begin{tabular}{|c|c|c|c|c|}
\hline & $\begin{array}{l}\text { Low } \\
\text { forage }\end{array}$ & $\begin{array}{l}\text { High } \\
\text { forage }\end{array}$ & $\mathrm{SE}$ & $P$ \\
\hline \multicolumn{5}{|l|}{ Eating time } \\
\hline per day & 194.9 & 199.1 & 5.5 & 0.52 \\
\hline per kg DMI & 8.3 & 9.2 & 0.3 & $<0.01$ \\
\hline per kg of NDF intake & 34.9 & 31.1 & 1.0 & $<0.01$ \\
\hline per $\mathrm{kg}$ forage NDF intake & 53.0 & 40.3 & 1.4 & $<0.0001$ \\
\hline \multicolumn{5}{|l|}{ Ruminating time } \\
\hline per day & 452.0 & 476.1 & 9.2 & 0.03 \\
\hline per kg DMI & 19.3 & 22.1 & 0.5 & $<0.0001$ \\
\hline per kg of NDF intake & 82.2 & 74.8 & 1.6 & $<0.001$ \\
\hline per $\mathrm{kg}$ of forage NDF intake & 125.4 & 97.5 & 2.4 & $<0.0001$ \\
\hline \multicolumn{5}{|l|}{ Total chewing time } \\
\hline per day & 646.9 & 675.2 & 11.4 & 0.04 \\
\hline per kg DMI & 27.6 & 31.3 & 0.6 & $<0.0001$ \\
\hline per $\mathrm{kg}$ of NDF intake & 117.1 & 105.9 & 2.1 & $<0.0001$ \\
\hline per $\mathrm{kg}$ of forage NDF intake & 178.3 & 137.8 & 3.0 & $<0.0001$ \\
\hline
\end{tabular}

4b). As a result, total tract NDF digestibility tended to increase more in the cows on LF than on $\mathrm{HF}$ as production increased (Figure 4c). Among moderateproducing cows, total tract NDF digestibility was similar for both $\mathrm{HF}$ and LF (Figure 4c).

Among moderate- to high-producing cows, the filling effects of the diets also probably affected the relative responses to $\mathrm{LF}$ and $\mathrm{HF}$, but chewing effectiveness may have become the dominant factor limiting intake and passage in those cows. When pretrial production level increased from approximately 26 to $32 \mathrm{Mcal} / \mathrm{d}$, the difference between NDF turnover times on LF and HF decreased as pMEO increased, and among the highest producers, the turnover times were similar between the two diets (Figure 4a). As pMEO increased from moderate to high production, the response (LF-
$\mathrm{HF}$ ) for NDF pool and total tract NDF digestibility also tended to decrease (Figure 3b,c); also, responses in INDF $k_{p}$ and time ruminating per kilogram of rumen NDF both increased for LF more than for HF (Figure 3d,e). Among these high-producing cows, NDF turnover times may have decreased on LF because of the filling effect of increased intake. Because the filling effect was even greater on HF than on LF (Figure $4 \mathrm{~b}$ ), the passage rate of INDF might be expected to increase more per unit pMEO on HF than on LF if fill were the dominant factor limiting intake on both diets. However, the inverse actually occurred among the highest producers (Figure 4d), indicating that fill was not the primary factor limiting intake on $\mathrm{HF}$ at high production. Rather, cows on $\mathrm{HF}$ may have reached a threshold in absolute chewing time, resulting in decreased time spent ruminating per kilogram of rumen NDF on $\mathrm{HF}$ relative to $\mathrm{LF}$, so that the response $(\mathrm{LF}-\mathrm{HF})$ in time ruminating per kilogram of rumen NDF increased with pMEO (Figure 4e). Thus, particle size reduction of rumen NDF slowed on $\mathrm{HF}$ relative to LF. A slower rate of ruminal particle size reduction on $\mathrm{HF}$ relative to $\mathrm{LF}$ would result in the presence of a smaller percentage of forage particles below the size threshold for passage from the rumen on $\mathrm{HF}$ than on LF, so that passage rate could not respond to increasing fill on $\mathrm{HF}$ as it did on LF (Figure 4d). An increasingly faster passage rate of NDF on the low-forage diet relative to the high-forage diet would then result in a shorter relative retention time (Figure 4a) and less thorough digestion of NDF on LF relative to $\mathrm{HF}$. Therefore, the response in total tract $\mathrm{NDF}$ digestibility on LF relative to HF tended to be-

Table 9. Least squares means, standard errors, and significance of effects of dietary fiber concentration on digestion kinetics in the rumens of cannulated cows.

\begin{tabular}{lcccr}
\hline & \multicolumn{2}{c}{ Treatment } & & \\
\cline { 2 - 3 } & Low forage & High forage & SE & $P$ \\
\hline Rumen pool size (kg) & & & & \\
DM & 11.3 & 11.3 & 0.5 & 0.89 \\
OM & 10.5 & 10.4 & 0.3 & 0.91 \\
NDF & 6.0 & 6.3 & 0.2 & 0.16 \\
Digestible NDF & 2.4 & 2.4 & 0.1 & 0.56 \\
Indigestible NDF & 3.6 & 3.9 & 0.1 & $<0.01$ \\
Starch & 0.99 & 0.67 & 0.07 & $<01$ \\
Ruminal turnover time (h) & 12.3 & & 0.5 & 0.14 \\
DM & 11.2 & 13.1 & 0.4 & 0.11 \\
OM & 25.3 & 12.0 & 0.8 & 0.01 \\
NDF & 29.6 & 22.7 & 0.9 & 0.31 \\
Indigestible NDF & 3.0 & 28.5 & 0.3 & 0.84 \\
Starch & 3.44 & 3.1 & 1.9 & 0.39 \\
$\mathrm{k}_{\mathrm{p}}$ indigestible NDF $\left(\mathrm{h}^{-1}\right)$ & 71.2 & 3.65 & 2.6 & 0.01 \\
Rumen digesta weight $(\mathrm{kg})$ & 85.2 & 77.7 & 0.01 & 0.02 \\
Rumen digesta volume $(\mathrm{L})$ & 0.84 & 92.9 & & 0.92 \\
Rumen digesta density $(\mathrm{kg} / \mathrm{L})$ & & 0.84 & & \\
\hline
\end{tabular}


Table 10. Least squares means, standard errors, and significance of effects of dietary fiber concentration on rumen fermentation.

\begin{tabular}{lcccc}
\hline & \multicolumn{2}{c}{ Treatment } & & \\
\cline { 2 - 3 } & Low forage & High forage & SE & $P$ \\
\hline VFA pool (mol) & & & & \\
Total & 8.77 & 9.51 & 0.40 & 0.11 \\
Acetate & 5.13 & 5.96 & 0.24 & 0.01 \\
Propionate & 2.20 & 2.05 & 0.11 & 0.23 \\
Lactate & 0.0029 & 0.0050 & 0.0014 & 0.31 \\
Butyrate & 1.00 & 1.05 & 0.09 & 0.68 \\
Branched chain VFA & 0.19 & 0.20 & 0.02 & 0.46 \\
Total VFA (mM) & 143.0 & 138.3 & 4.4 & $<0.0001$ \\
VFA (mol/100 mol) & & 63.1 & 0.50 & 0.0001 \\
Acetate & 58.5 & 21.6 & 0.52 & 0.42 \\
Propionate & 25.4 & 11.4 & 0.32 & $<0.0001$ \\
Butyrate & 11.8 & 2.17 & 0.07 & 0.07 \\
Branched-chain VFA & 2.23 & 2.96 & & \\
Acetate:Propionate & 2.32 & & &
\end{tabular}

come increasingly negative among the highest-producing cows (Figure 4c).

\section{SUMMARY}

A decreasing $\mathrm{F}: \mathrm{C}$ did affect the average responses in some aspects of feeding, digestion, and production. However, responses in production, energy balance, and digestion of NDF were usually dependent upon potential milk production as estimated by pFCMY and pMEO.

Responses to LF over HF in energy partitioning between maintenance, milk, and reserves displayed a quadratic relationship to pretrial milk energy output, indicating that different factors determined partitioning as milk production increased. As milk yield increased from low to moderate, the additional energy available from LF was increasingly devoted to re- serves rather than production. From moderate to high production, cows responded to LF by increasing the proportion of absorbed energy used for milk output. The kinetics of NDF digestion in the rumen also responded to forage level by quadratic relationships with pMEO. As production increased from low to moderate, ruminal turnover time of NDF on the low forage diet increased relative to turnover time on the high forage diet. Among high-producing cows, NDF processing on the high forage diet may have been limited by the cows' inability to increase time spent ruminating.

\section{CONCLUSIONS AND IMPLICATIONS}

Individual responses of intake, production, and fiber digestion to a change in $\mathrm{F}$ : $\mathrm{C}$ were dependent on production level. The effect of production level on re-

Table 11. Responses (low forage-high forage) of rumen kinetics, fermentation, total tract digestibility and chewing behavior by pretrial milk $\mathrm{NE}_{\mathrm{L}}$ output $(\mathrm{pMEO})^{1}$ in cannulated cows.

\begin{tabular}{|c|c|c|c|c|c|}
\hline Response & $\mathrm{R}^{2}$ & Predictor & $P$ & Coefficient & Intercept \\
\hline \multirow[t]{3}{*}{ NDF turnover time $(\mathrm{h})$} & \multirow[t]{3}{*}{0.36} & Sequence & $<0.01$ & -2.46 & \multirow[t]{3}{*}{-78.99} \\
\hline & & pMEO & 0.05 & 6.30 & \\
\hline & & $\mathrm{pMEO}^{2}$ & 0.05 & -0.12 & \\
\hline \multirow[t]{3}{*}{ NDF pool (kg DM) } & \multirow[t]{3}{*}{0.45} & Sequence & $<0.01$ & -0.70 & \multirow[t]{3}{*}{-14.92} \\
\hline & & pMEO & 0.09 & 1.16 & \\
\hline & & $\mathrm{pMEO}^{2}$ & 0.09 & -0.02 & \\
\hline \multirow{4}{*}{$\mathrm{k}_{\mathrm{p}}$ (indigestible NDF) } & \multirow[t]{4}{*}{0.59} & Sequence & $<0.001$ & 0.66 & \multirow[t]{4}{*}{16.08} \\
\hline & & day & 0.05 & -0.32 & \\
\hline & & pMEO & 0.03 & -1.33 & \\
\hline & & $\mathrm{pMEO}^{2}$ & 0.03 & 0.03 & \\
\hline \multirow[t]{3}{*}{ NDF digestibility (total tract) } & \multirow[t]{3}{*}{0.67} & Sequence & 0.02 & 4.23 & \multirow[t]{3}{*}{-143.23} \\
\hline & & pMEO & 0.09 & 10.62 & \\
\hline & & $\mathrm{pMEO}^{2}$ & 0.09 & -0.20 & \\
\hline \multirow{2}{*}{ Ruminating time/kg rumen NDF (min/kg) } & \multirow[t]{2}{*}{0.50} & pMEO & 0.04 & -30.1 & \multirow[t]{2}{*}{368.4} \\
\hline & & $\mathrm{pMEO}^{2}$ & 0.03 & 0.60 & \\
\hline
\end{tabular}

${ }^{1}$ Pretrial milk NE output, calculated for $4 \mathrm{~d}$ before beginning of experiment: $\mathrm{NE}_{\mathrm{L}}(\mathrm{Mcal} / \mathrm{d})=\mathrm{MY}(\mathrm{kg} / \mathrm{d}) \times$ $(0.0929 \times$ fat $\%+0.0563 \times$ true protein $\%+0.0395 \times$ lactose $\%)($ NRC 2001$)$. 

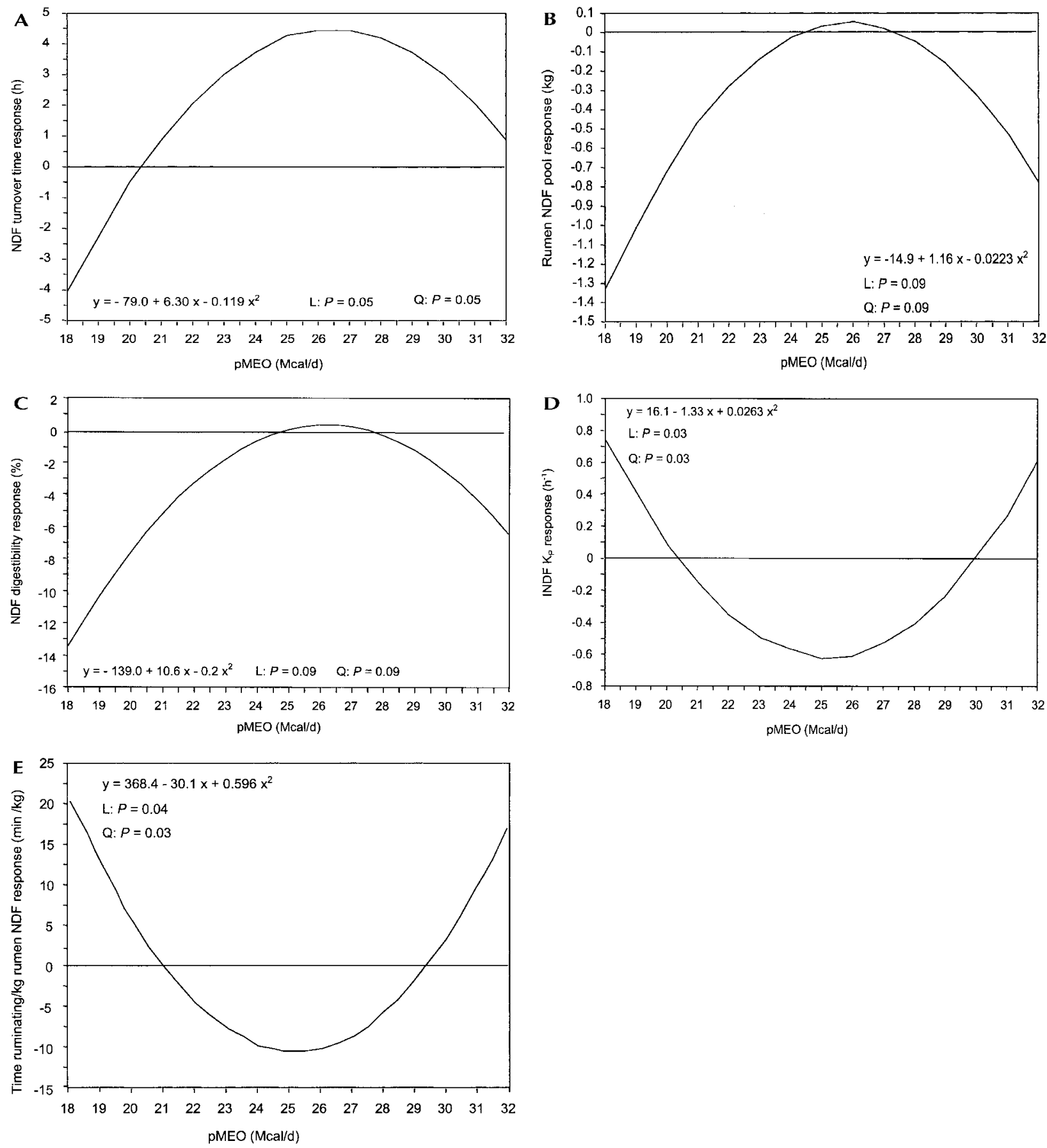

Figure 4. Relationship between mean pretrial milk $\mathrm{NE}_{\mathrm{L}}$ output over $4 \mathrm{~d}$ before the beginning of the experiment (pMEO) and the response to the low-forage over the high-forage diet (LF-HF) in (A) rumen NDF turnover time, (B) rumen NDF pool, (C) total tract NDF digestibility, (D) passage rate of indigestible NDF, or (E) time ruminating per kilogram of rumen NDF pool. 
sponse to dietary factors should be investigated further and should be considered in future studies of dietary characteristics. Finally, recommendations for feeding and diagnoses of nutritional problems on dairy farms should consider not only average characteristics and responses to diet, but also the range of production in the herd and the responses of cows at different production levels.

\section{ACKNOWLEDGMENTS}

The authors wish to thank D. G. Main, R. A. Longuski, Y. Ying, M. Oba, C. S. Mooney, R. E. Kreft, and the staff of the Michigan State University Dairy Cattle Teaching and Research Center for their assistance in this experiment.

\section{REFERENCES}

Alhadhrami, G., and J. T. Huber. 1992. Effects of alfalfa hay of varying fiber fed at 35 or $50 \%$ of diet on lactation and nutrient utilization by dairy cows. J. Dairy Sci. 75:3091-3099.

Allen, M. S. 1996. Physical constraints on voluntary intake of forages by ruminants. J. Anim. Sci. 74:3063-3075.

Allen, M. S. 2000. Effects of diet on short-term regulation of feed intake by lactating dairy cattle. J. Dairy Sci. 83:1598-1624.

Anil, M. H., J. N. Mbanya, H. W. Symonds, and J. M. Forbes. 1993. Responses in the voluntary intake of hay or silage by lactating cows to intraruminal infusions of sodium acetate or sodium propionate, the tonicity of rumen fluid or rumen distension. Br. J. Nutr. 69:699-712.

Association of Official Analytical Chemists. 1990. Official Methods of Analysis. 15th ed. AOAC, Washington, DC.

Cochran, R. C., D. C. Adams, J. D. Wallace, and M. L. Galyean. 1986. Predicting digestibility of different diets with internal markers: evaluation of four potential markers. J. Anim. Sci. 63:1476-1483.

Dado, R. G., and M. S. Allen. 1995. Intake limitations, feeding behavior, and rumen function of cows challenged with rumen fill from dietary fiber or inert bulk. J. Dairy Sci. 78:118-133.
Goering, H. H., and P. J. Van Soest. 1970. Forage Fiber Analysis (Apparatus, Reagents, Procedures, and Some Applications). Agric. Handbook No. 379. ARS-USDA, Washington, DC.

Grant, R. J. 1997. Interactions among forages and nonforage fiber sources. J. Dairy Sci. 80:1438-1446.

Grummer, R. R., A. L. Jacob, and J. A. Woodford. 1987. Factors associated with variation in milk fat depression resulting from high grain diets fed to dairy cows. J. Dairy Sci. 70:613-619.

Hach, C. C., B. K. Bowden, A. B. Lopelove, and S. V. Brayton. 1987. More powerful peroxide Kjeldahl digestion method. J. AOAC 70:783-787.

Hoover, W. H. 1986. Chemical factors involved in ruminal fiber digestion. J. Dairy Sci. 69:2755-2766.

JMP User's Guide: Statistical Discovery Software, Version 4 Edition. 2000. SAS Inst., Inc., Cary, NC.

Johnson, T. R., and D. K. Combs. 1992. Effects of inert rumen bulk on dry matter intake in early and midlactation cows fed diets differing in forage content. J. Dairy Sci. 75:508-519.

Karkalas, J. 1985. An improved enzymatic method for the determination of native and modified starch. J. Sci. Food Agric. 36:1019-1027.

Lehman, F. 1941. Die lehre vom ballast. Z. Tierphysiol. Tierernaehr. Futtermittelkd. 5:155-173.

Mertens, D. R. 1994. Regulation of forage intake. Pages 450-493 in Forage Quality, Evaluation, and Utilization. G. C. Fahey, Jr., M. Colins, D. R. Mertens, and L. E. Moser, eds., American Society of Agronomy, Crop Science Society of America, and Soil Science Society of America, Madison, WI.

National Research Council. 2001. Nutritional Requirements of Dairy Cattle. 7th rev. ed. Natl. Acad. Sci., Washington, DC.

Oba, M., and M. S. Allen. 1999. Effects of brown midrib 3 mutation in corn silage on dry matter intake and productivity of high yielding dairy cows. J. Dairy Sci. 82:135-142.

Sheperd, A. C., and D. K. Combs. 1998. Long-term effects of acetate and propionate on voluntary feed intake by midlactation cows. J. Dairy Sci. 81:2240-2250.

Van Soest, P. J., J. B. Robertson, and B. A. Lewis. 1991. Methods for dietary fiber, neutral detergent fiber, and nonstarch polysaccharides in relation to animal nutrition. J. Dairy Sci. 74:3583-3597.

Weimer, P. J., G. C. Waghorn, C. L. Odt, and D. R. Mertens. 1999. Effect of diet on populations of three species of ruminal cellulolytic bacteria in lactating dairy cows. J. Dairy Sci. 82:122-134.

Wheeler, W. E., C. H. Noller, and C. E. Coppock. 1975. Effect of forage-to-concentrate ratio in complete feeds and feed intake on digestion of starch by dairy cows. J. Dairy Sci. 58:1902-1906.

Wildman, E. E., G. M. Jones, P. E. Wagner, R. L. Boman, H. F. Troutt Jr., and T. N. Lesch. 1982. A dairy cow body condition scoring system and its relationship to selected production characteristics. J. Dairy Sci. 65:495-501. 